\title{
CITIES AS WAYS OF WORLDMAKING
}

\author{
A B S S T R A C T
}

The theme of "Ways of Worldmaking" appears in the writings of philosophers such as Ernst Cassirer and Nelson Goodman. Cassirer takes up this theme in Language and Myth (Tr. by Susan Langer (Harper, 1946)), and Goodman addresses "The Ways of World Making" in his book bearing the same title (Hackett, 1978, 1981). Both philosophers cite the arts as key ways of world making in their function as various forms of symbols. Following the insights of Cassirer and Goodman, "Ways of Worldmaking" is explored here first in reference to an imaginative world making roles of works of the arts that relate to cities. Examples including the literary works of J. R. R. Tolkien, an opera by Kurt Weill and Berthold Brecht, a film by Chinese artist Xu Bing, New York's Hudson Yards, the biggest private real estate development in US history to date, are used as instances of worldmaking in the arts and city development.

WORLDMAKING

CITY

TOLKIEN

KURT WEILL | BETHHOLD BRECHT

XU BING

HUDSON YARDS

NELSON GOODMAN

ERNST CASSIRER 
The theme of "Ways of Worldmaking" appears in the writings of philosophers such as Ernst Cassirer and Nelson Goodman. Cassirer takes up this theme in Language and Myth (Tr. by Susan Langer, Harper, 1946), and Goodman addresses "The Ways of Worldmaking" in his book bearing the same title (Hackett, 1978, 1981). Both philosophers cite the arts as key ways of worldmaking in their function as various forms of symbols. For Cassirer, art as a form of worldmaking originates in imagination and gives us 'the intuition of the form of things ... as a true and genuine discovery'. ${ }^{1}$ Art offers a perspective that differs from ordinary seeing as well as from the impoverished abstractions of science based on facts or purported natural laws.

In his book Ways of Worldmaking, Goodman examines the formative functions of symbols by asking probing questions about our use of language/literature, pictures, and other types of symbols to create worlds of understanding. For example, he asks, 'In just what sense are there many worlds? What distinguishes genuine from spurious worlds? How are they made? ... And how is worldmaking related to knowing?'2 Goodman holds that 'the arts must be taken no less seriously than the sciences as modes of discovery, creation, and enlargement of knowledge' in their role of advancement of understanding. ${ }^{3}$

Following the insights of Cassirer and Goodman, 'ways of worldmaking' is explored here first in reference to an imaginative world making roles of works of the arts that relate to cities. The role of cities in world making is no stranger to philosophers as Plato reminds us in his book Republic (Book II) with these words: '.. A city comes to being because none of us is self-sufficient, but we all need many things' ${ }^{4}$ Works of art including the literary works of J. R. R. Tolkien (1937, 1936-1949), the o "Mahagonny" opera by Kurt Weill and Berthold Brecht (1930), Xu Bing's recent film "Dragon Fly Eyes" (2017), and New York's Hudson Yards, the biggest private real estate development in US history unveiled in 2019, are used as instances of worldmaking with respect to the arts and city development.

Hence, the aim of this essay is to explore various manifestations of worldmaking in a selection of arts relating to worldmaking of fictive cities in the arts, and then in reference to the formation of contemporary cities themselves as ways of worldmaking illustrated by Hudson Yards. 


\section{TOLKIEN AND WAYS OF WORLDMAKING}

My interest in worldmaking in connection with Tolkien began with an exhibition at the Haggerty Museum entitled "The Invented Worlds of J. R. R. Tolkien". As it happens recent scholarship on Tolkien appears to be notably focused on the theme of worldmaking. Among recent publications on Tolkien's works is the 2019 publication Sub-creating Arda: World Building in J. R. R. Tolkien's Word, it Precursors, and Legacies, edited by Fimi and Honegger. ${ }^{6}$ The insights into these texts especially relevant to the topic of this paper include Andrew Higgins' account of Tolkien's literary and graphic means used in building of his world of "Arda" which includes The Hobbit and The Lord of the Rings. These works use maps, charts, genealogies, and both lexicons and grammar of invented languages. Such literary and graphic means are used both to construct the worlds and to generate the interaction and transaction between an author and a reader. ${ }^{7}$ At the core of Tolkien's invented worlds is the assumption that 'language creates the reality it describes'. ${ }^{8}$ In this respect, he holds similar views to those of Goodman, who understands languages as entirely constructed symbol systems. Like Goodman, Tolkien did not limit his sense of languages to written texts.

The Hobbit, which appeared in 1937, and The Lord of the Rings, first published in three volumes in 1954-55, both suggest immediately the theme of worldmaking. It is not the worldmaking of statesmen that occupies Tolkien. Rather it is worldmaking made possible through the author's imaginative constructions using words. Tolkien's literary texts cannot be fully appreciated apart from a larger, philosophical issue concerning language. His childhood fascination with inventing languages eventually led him to the study of languages. For Tolkien, a language is a wholly invented enterprise constructed by the mind, or a set of minds, and has no natural existence apart from its invention and use by the human mind, or a set of minds.

Fewer people are aware of the fact that Tolkien was a talented visual artist not having had the opportunity to view his original drawings and watercolour paintings. These works are known primarily as the illustrations for The Hobbit and The Lord of the Rings and other of his texts. ${ }^{9}$ His paintings and drawings offer further insight into Tolkien's imagined cities. ${ }^{10}$

For our purposes here, the central question that needs to be answered: in what sense might Tolkiens's literary and visual images contribute to the theme of worldmaking in general and, perhaps also to our understanding of a city as a worldmaking form? The intent here is not to make a full-blown claim or to 
overstate this possibility, but to use Tolkien's ventures into worldmaking as a start for this discussion in the several media proposed here. Rather, it is to show how the city plays a role in his imaginative literary explorations.

\section{TOLKIEN AND CITIES}

Although Tolkien offers no exolicit characterisation of a city as it might be defined by urban theorists such as Lewis Mumford in his classic study, The City in History: Its Origins, its Transformations and its Prospects (1961), Kevin Lynch's The Image of The City (1960), or Edward Glaeser's Triumph of the City (2011), Tolkien's recent scholarship has focused on the city as an important topic in The Hobbit and Lord of the Rings, two of his major works. ${ }^{11}$ For example, Dominika Niez's essay, "The Forest and the City: the Dichotomy of Tolkien's Istari” considers the author's interest in contrasting the city with a forest. In this context two wizards, Radagast with connections to the forest life and nature and Saruman identified with the city and the forces of industrialisation, offer a context for comparing city life with life in the forest.

By the early twentieth century, Birmingham, England, where Tolkien spent part of his early life, became a thriving city with a history of architectural and industrial development, also reflecting the growing city problems associated with industrialisation. Tolkien himself grew up in the city's Edgbaston area in the shadow of Perrott's Folly and the Victorian tower of Edgbaston Waterworks, which are possibly sources of images for dark towers that appear in his works. ${ }^{12}$ Also part of Tolkien's childhood was the Birmingham Museum, with a collection which included fine art, natural history archaeology, as well as local history and industrial history. It would be an interesting study to explore whether and to what extent Tolkien's literary or visual images of city might have been influenced by the architecture and other aspects of his life in Birmingham. As it turns out, Tolkien favours forest over city in his literary works. This theme is developed in Helen Conrad-O'Brian's and Gerard Hynes' (editors) Tolkien: The Forest and the City (2013). ${ }^{13}$

Let us turn to Tolkien's views of the city in his The Hobbit and The Lord of the Rings. With respect to population, Hobbits, Elves, and Dwarfs are among those who reside in Tolkien's literary worlds. A Hobbit, the main character, is one of imaginary characters in Tolkien's works. Hobbits, seemingly the main characters, are people-like characters, who give themselves this name meaning "hole-dweller". Others refer to them as "halflings" because they were half the height of normal men. ${ }^{14}$ The Hobbit is populated with diverse occupants 
including Dwarfs and Goblins. These characters, whose interests are not always compatible with each other, were also not immune to external threats, such as a dreaded dragon named Smaug. Similarly, quarrels leading to wars among different groups led to conflicting interests and power struggles the likes of which we are familiar in the world of cities outside of fiction.

The dwelling spaces in The Hobbit consist mainly of structures set in imaginary cities and landscapes in the midst of mountains and waterways. Although seemingly smaller in scale when compared to portrayal of cities depicted in Lord of the Rings, the cities depicted in The Hobbit entertain at least some of the characteristics that demarcate city beyond Tolkien's literary walls. Within The Hobbit Tolkien assigns names to geographic locations with characteristics of cities. For example, Lake Town, Dale, Esgaroth, and Aberstore. Like city spaces in the non-fictional world, those in Tolkien's literary discourses include certain trademarks: City Gates and walls which regulate access and security are some of the features of the city landscape in The Hobbit. Additional features of such sites include Great Halls (the Hall of Feasting and of Council) that serve as gathering spaces symbolising important community gatherings.

As the community of Esgaroth in The Hobbit assesses the damages to the city from a battle with the defeated dragon Smaug, we find a model for addressing urban disaster. In Tolkien's narrative there is an understanding of key factors a city might need to address in a period of reconstruction after war or major natural disasters. As we might expect, providing food for the needy and care for the sick and injured are some of the immediate efforts in responding to a disaster.

Questions about leadership, debates over whether a new regime or the existing one is best suited to undertake the reconstruction, and attention to new plans for the future are among the issues that the community of Esgaroth addresses. For example, should the Master retain his position as a leader or should Bard, a descendant of the king, who had used his ancestral Black Arrow to destroy the Dragon, lead the restoration planning? After looking at the ruins of their city and available resources, including a store of gold previously guarded by the Dragon, the leaders of Esgaroth began planning a new city more fair and larger than before. ${ }^{15}$ Such sentiments seem to echo the planning needs of cities in the modern world outside Tolkien's literature. Of course, the question of how to fund these changes in the city depend on available resources. And here the citizens benefited from a treasure of gold liberated from the Dragon. 
Tolkien's fictive world of The Hobbit is not immune from discrimination based on differences among its populations, which contaminates the world that we inhabit. An example of this in the book is Beorn, who remarks that he is not overly fond of Dwarfs. On the other hand, while cautioning against trusting strangers, Beorn warmly extends hospitality and gifts his visitors food and ponies passing through Mirkwood.

Tolkien's account of cities continues in The Lord of the Rings as the characters travel through the lands. In Fellowship of the Ring, Part I of Lord of the Rings, we find an account of the city Minas Tirith as viewed from a distance by Frodo during a battle: 'Far away it seemed and beautiful: white washed, manytowered, proud and fair upon its mountain-seat; its battlements glittered with steel, and its turrets were bright with many banners'. ${ }^{16}$ In Part III, Book 5, the city of Minas Tirith is described: 'For the fashion of Minas Tirith was such that it was built on seven levels, each delved into the hill, and about each was a set wall, and in each wall a gate'. In a passage from The Lord of the Rings 'Pippin gazed in growing wonder at the great stone city, vaster and more splendid than anything that he had dreamed of ...' ${ }^{17}$

In contrast to the imagined cities in The Lord of the Rings is the account of the Old Forest:

'The Forest is queer. Everything in it is very much more alive, more aware of what is going on so to speak ... And the trees do not like strangers. They are usually content merely to watch you, as long as daylight lasts, and don't do much. ... But at night things can be most alarming ... I thought all the trees were whispering to each other, passing news and plots along in an unintelligible language, and the branches swayed and groped without any wind'. ${ }^{18}$

The city in Tolkien's literary schemes anticipate some of the problems of cities with their focus on the changing character of non-fictional cities and the problems they must address in the aftermath of war and natural disaster. His imaginative descriptions point to creative constructions that anticipate the modern cities, but without the interactive technologies that have not yet arrived even in imagination.

Hence works of fiction such as Tolkien's The Hobbit and The Lord of the Rings command a noteworthy role in worldmaking. They function not as literal description, but as a metaphorical alternative view of the world that may actually live in the experiences of those who read Tolkien's text or view his 
visual images, or otherwise participate in them. As works of literature, Tolkien's constructed worlds are not the world of the physicist, or of the people we meet on the street. But they may nevertheless inform and enrich the worlds of both. His visual art augments the literary scenes found in his books. ${ }^{19}$ Given these examples from Tolkien's literary and visual contributions to worldmaking it would seem that his art exemplifies the imaginative worldmaking anticipated in the philosophical theories of Cassirer and Goodman.

\section{WORLDMAKING IN THE RISE AND FALL OF THE CITY OF MAHAGONNY}

Worldmaking can occur in a musical theatre as well as in literary and visual arts. At times, artists see as their role to challenge or critique the options accessible in city life. "Rise and Fall of the City of Mahagonny" by Kurt Weil (music) and Berthold Brecht (lyrics) first presented in the 1930s during the Nazi era in Germany, sets forth in song and drama the conditions of an imagined city life gone awry.

'The city of Mahagonny, in which Brecht's tragic play takes place, is a symbolic caricature of freedom: a legendary place, where everyone can live as he pleases ... It is founded and populated by adventurers, wrecked human beings, criminals, procurers, ad prostitutes. ... The frontiers are set by the rules of supply and demand. ${ }^{20}$

Initially, the city of Mahagonny was intended as a model city aimed at offering useful services to its residents. But this model city soon degenerates as abuse of power and greed lead to an environment where commodification of goods and services leads to the demise of bourgeois civilities. Mahagonny thus offers a critique of both social conditions and human vulnerabilities that may take place in the process of worldmaking. The fictive city of Mahagonny in Weil/ Brecht's theatrical creation is intended as a parable of a city culture gone awry as it fosters an environment where commodification of goods and services leads to the demise of bourgeois civility. The extreme of life in Weill/Brecht's fictive Mahagonny shows poverty as a crime warranting punishment. The aim of Weil's music, including jazz rhythms, in the context of classical musical forms was to 'get people involved and thinking'.

At the time of its introduction in the 1930s, Weill's musical production posed a challenge to life in the state of Weimar, Germany, and especially to the emerging Nazi view of culture, making it necessary for him exile to the United States. There he collaborated with Moss Hart, Ira Gershwin, and Langston Hughes on enriching the cultural life of another lively city with Broadway musical successes: New York. ${ }^{21}$ 
A moment of reflection on the decadent conditions of life in Weill's city reminds us that our current state of city life also faces many challenges, perhaps not yet as extreme as the deteriorated conditions in Mahagonny. To be sure some of our problems such as corruption emerge from deficiencies in human character. But more pertinent to our concerns here are issues such as the increased commodification of city life, poverty, and the de-emphasis on the values (justice, respect, trust) necessary to support attention to such matters. From the perspective of social aesthetics, what then will be the role of the arts in these new social processes? How will art and aesthetics fare in these social changes? What new forms will the arts currently emerging in contemporary city life offer to present and future generations?

Despite its dour lessons referencing city life in disarray, Mahagonny continues to enjoy periodic revivals. In addition to the U.S. productions in New Haven in 1974 and 1978, the Metropolitan Opera in New York in 1979, and Los Angeles in 2017, its productions continue to be held in theatres across the world. There is now (2017) a festival in Dessau, Germany, the home of the Avant-garde Bauhaus, where Weill is increasingly celebrated including a recent production of "The Rise and Fall of the City of Mahagonny". The continuation of recurring revivals of Weil's enigmatic commentary on city life reminds us that one of the ways in which art has functioned in city life is by continuously reviving the arts of the past through restaging and reinterpreting past contributions.

Weil and Brecht were not alone in their challenge to the narratives of life in Germany at the time. They were joined by radical artists including the painter Otto Dix and architect Mies Vander Rohe, cabaret performers and other artists regarded as degenerate in the eyes of the Third Reich.

\section{XU BING: “DRAGONFLY EYES”}

Taking the discussion of worldmaking to a contemporary stance where film is the medium, Chinese contemporary artist Xu Bing's recent film, "Dragonfly Eyes" was released in 2017. Among Xu Bing's never-ending pursuit of new challenges, this cameraless experimental film is based on footage acquired from some 500 surveillance cameras and online streaming images of city life. The film ostensibly narrates a simple story centring on the lives of two characters, Wing Ting (Dragonfly) and her boyfriend Siao Xiao as they navigate through a series of identity changes in contemporary Chinese city life. It also shows the strains of everyday urban life of the twenty-first century. "Dragonfly Eyes" will generate conversations and concerns over the millions of security cameras 
that focus on nearly all aspects of contemporary city life, whether in Beijing or New York or London, from the maintenance of street traffic and public safety to national security issues and possibly intrusions into the privacy important to everyday life.Apart from its creative advances in experimental film making, this work vividly draws our attention to what may well be a grave threat to values based on personal freedom as it is lived out in the twentieth century cities and beyond. While the artist in this work is also concerned with unlocking new aspects of creating art film, there is no doubt that Xu Bing's film brings the role of surveillance devices in the twenty-first century city life under a sharp focus.

"Dragonfly Eyes" was shown in the New York Film Festival in 2017 and was included in Xu Bing's Ullens Center exhibition in 2018.

\section{HUDSON YARDS}

Taking the discussion of "Ways of Worldmaking" into the actual world of city spaces, I will briefly turn to the contemporary city as a form of worldmaking by examining the latest city development in New York City called Hudson Yards, which opened officially in March of 2019. ${ }^{22}$ This recent contribution to worldmaking joins other such projects in New York, such as the 92-acre publicly developed Battery Park City completed in 2011, and Lincoln Center created in 1955 , which is currently the cultural hub of the city, housing major performance spaces of dance, theatre and music in New York. Unlike the publicly developed 92-acre Battery Park City embodying the urban ideals of urban theorist and reformer Jane Jacobs, Hudson Yards consists of a privately developed 28-acre section of Manhattan. This development is located along Tenth Avenue over what previously served as a 30 track Hudson Yards rail yard. ${ }^{23}$ 'The development has reimagined a neighbourhood once dominated by rundown industrial buildings and auto repair shops as an architectural landmark'. ${ }^{24}$

Unlike previous urban projects in New York such as Battery Park, Hudson Yards was built by a single development company, headed by Stephen Ross. Hudson Yards includes a cluster of residential, commercial, retail, and cultural spaces featuring high-rise towers containing office spaces, apartments, an extensive mall and green spaces. Taking note of increasing terrorist threats, Hudson Yards developers are mindful of security needs and the capacity to cope with natural disasters. The development applies the latest technology in its systems, including its own power system, rainwater collection system, and protection against storms, and of course elaborate security features. ${ }^{25}$ 
A place for the arts in Hudson Yards is invested in The Shed, a USD 475 millioncentre for the arts designed by Diller, Solidi, Renfo, in collaboration with the Rockefeller Group. ${ }^{26}$ The aim of the planners for the Shed was to create a highly flexible cultural entity with architecture that would encourage artists to break out of their narrowly construed discipline offerings and connect with other disciplines: dancers with visual artists, musicians with theatrical performances aimed at reaching a greater number of people. ${ }^{27}$ Not to be missed in this addition to worldmaking is Vessel, a 154-high vertical sculpture of connected staircases designed by Thomas Heatherwics Studios in London, that aspires to rival the Eiffel Tower in Paris. ${ }^{28}$

All of the elements set forth in the Hudson Park project at the moment anticipate a next stage in worldmaking representing a new development in city planning. Such a development generates hope for improvements, enrichments in future city life by including latest technologies, and a museum of contemporary architecture featuring buildings designed by leading architects such as Frank Gehry, Santiago Calatrava, Robert A. M. Stern.

Looking at this newest manifestation of worldmaking from a more distant perspective, it is interesting to consider how Hudson Yards was received by Jane Jacobs, an urban activist and urban planner who challenged the urban planning ideals of the 1950 s to 1980 s and questioned the value of tall buildings isolated from street life. ${ }^{29}$ Jacobs would no doubt be sceptical about the volume of high-rise buildings and the limited connection to adjacent street life.

Such worldmaking enterprises are not immune to criticism from contemporaries. New York Times architecture critic Michael Kimmelman finds Hudson Yards lacking in a semblance of human scale. 'Hudson Yards glorifies a kind of surface spectacle - as if the peak ambitions of city life were consuming luxury goods and enjoying a smooth, seductive, mindless materialism ${ }^{\prime}{ }^{30}$ In defence of Hudson Yards is the view of Patricia Derrington, Director of the Center of Urban Real Estate, Columbia University: 'This is how urban folk choose to live: a defined neighbourhood that represents their values and aspirations, set in amongst others of a different identity'. ${ }^{31}$

\section{CONCLUSION}

The examples of worldmaking with respect to cities in three different art forms (literature, music, and film), and city planning each offer insights into worldmaking. From Tolkien's literary texts we see references to the imagined 
city constructions and skeletal sketches of issues necessary to city life including glimpses of fictive architecture as contrasted with nature in the forest and the needs for governance and social life although basic in character. Weil and Brecht's Mahagonny, we witness the breakdown of city life exhibiting human both the frailties of the human condition and hope for the future reconstruction of a broken city structure.

Xu Bing draws attention to invasive forces in city life by means of a relative new intervention consisting of the surveillance camera in his "Dragonfly Eyes". The interventions of invasive security devices into almost every aspect of human life poses a threat to worldmaking issues related to personal values such as privacy and given unlimited access to state authorities as well as to predators. Xu Bing's film, while itself relying on exploratory possibilities of inventive surveillance technologies, also points to a growing social concern with the possible uses of surveillance devices for intervention in personal life. In the surveillance camera, we have a contribution to worldmaking that raises important questions concerning the rights of personal liberty versus the government and other social forces access to personal life privacy. Not all worldmaking practices and their uses are necessarily good for the mankind. And here is a case where the arts can contribute to the discussion of the role of such devices.

Moving our discussion of worldmaking into the "real world" city planning, Hudson Yards is an example of city planning that directly affects the material, social, and economic structure of an actual city. New York is one of the great cities in the world, where the lives of countless residents and visitors either benefit or suffer from the actions resulting in a major shift in shaping the future life of New York as a city.

In short, the importance of worldmaking with reference to cities is aptly noted in Edward Glaeser's Triumph of the City: 'Great cities are not static - they constantly change and take the world along with them' ${ }^{32}$ 
Ernst Cassirer, Language and Myth, translated by Susanne K. Langer (New York: Dover Publications, 1946). Ibid., 102

Plato, Republic, translated by G. M. A. Grube (Indianapolis, Hackett Publishing Co., 1992), 44.

Curtis L. Carter, "Ways of Worldmaking: J. R. R. Tolkien," in The Invented Worlds of J. R. R. Tolkien: Drawings and Original Manuscripts from the Marquette (University Collection, October 21, 2004-January 2005), 7-16.

Dimitri Fimi and Thomas Honegger (editors), Sub-creating Arda: World-Building in J. R. R. Tolkien's Works, its Precursors, and Legacies (Walking Trees Publishers: Zurich and Berne, Switzerland, 2019). According to the Editors Tolkien preferred to address his literary world building as "sub-creation". Current interest in this topic is also reflected in a call for papers focused on Tolkien and the Classical World which notes, 'Scholarship on J. R. R. Tolkien has become more and more interested in the topic of worldbuilding ...'. 
and Thomas Honegger (Walking Tree Publishers: Zurich and Berne, Switzerland, 2019). Available at: http://www.walking-tree.org/books/sub-creating_arda.php?openmenuitems=publ\#t.

Verlyn Flierger, Splintered Light: Logos and Language in Tolkien's World (Kent and London: Kent State University Press, 2002), xxi.

Tolkien created the illustrations for The Hobbit, The Silmarillion, The Lord of the Rings, Farmer Giles of Ham, The Father Christmas Letters, Mr. Bliss, and other texts.

Tolkien's original paintings and drawings are located at the Bodleian Library, Oxford University and the Special Collections of the Raynor Library, Marquette University.

Lewis Mumford, The City in History: Its Origins, its Transformations and its Prospects (USA: Harcourt, Brace and World, 1961); Kevin Lynch, Image of the City (Cambridge, Massachusetts, 1960), or Edward Glaeser, Triumph of the City (New York: Penguin Press, 2011).

Jr. R. R. Tolkien Archived 29 April 2011 at the Wayback Machine, Archives and Heritage Forum. Retrieved 27 April 2009. Cited

Helen Conrad-O'Brian and Gerard Hynes, Editors, Tolkien: The Forest and the City (Four Court Press, 2013), 67-75.

Humphrey Carpenter, editor with the assistance of Christopher Tolkien, The Letters of J. R. R. Tolkien (Boston: Houghton Mifflin ,1981), No. 316, 405.

J. R. R. Tolkien, The Hobbit (London, Sidney: Unwin \& Hyman, Anniversary Edition, 1987), 216.

J. R. .R. Tolkien, Fellowship of the Ring: Lord of the Ring (Boston, Houghton Mifflin, 1954, 1965), 417.

J. R. R. Tolkien, the Return of the King (Boston, Houghton Mifflin, 1992), 782.

J. R.R. Tolkien, The Fellowship of the Ring: The Lord of the Rings (Boston: Houghton Mifflin, 1992), 125.

Richard Schindler, The Expectant Landscape: J. R. R. Tolkien's Illustrations for the Hobbit; J. R. R. Tolkien: The Hobbit: Drawings, Watercolors, and Manuscripts, Exhibition Catalogue (Milwaukee: Marquette University, June 11-September 30, 1087), 17-19.

Kurt Weill and Berthold Brecht, Rise and Fall of the City of Mahagonny (Libretti of North German Radio Chorus Production), 15.

Joshua Barone, "Kurt Weill: How Germany Finally Unearthed a National Treasure," New York Times (March 9, 2017).

Hudson Yards is located in New York City between $30^{\text {th }} \& 4^{\text {th }}$ North $\&$ South, and $10^{\text {th }}$ and $12^{\text {th }}$ East and West. It designers are Kohn, Pederson, Fox and its developer is Stephen Ross. Although funded as a private development, indirect public costs included 1.4 billion for 4 acres of park and open space 2.4 billion to extend No. 7 subway, and 359 million interest on bonds.

C. J. Hughes, “Giants Within A City of Giants," The New York Times (April 7, 2-19): 10.

Ibid.

Peter Grant, "Hudson Yards Design is Like a Fortress," The Wallstreet Journal (March 13, 2019).

Nick Mafi, "The Shed Finally Opens in New York City's Hudson Yards," (April 5, 2019).

Michael Cooper, “Can the Shed Redeem Hudson Yards?,” New York Times (March 31, 2019).

Andrew Russeth, "Stairway to Nowhere: on the Pleasure of Hating Thomas Heatherwisc's vessel in Hudson Yards," Art News (March 3, 2019).

Jane Jacobs, The Death and Life of Great American Cities (New York: Random House, 1961); Edward Glaeser, Triumph of the City (New York: The Penguin Group, 2011), 142-148.

Michael Kimmelman, "Hudson Yards is Manhattan's Biggest, Newest, Slickest Gated Community," The New York Times (March 14, 2019).

Barbara Goldberg, "Hudson Yards Redraws New York Skyline," Reuters (March 15, 2019).

Edward Glaeser, Triumph of the City (New York: Penguin Group, 2011). 
Barone, Joshua. "Kurt Weill: How Germany Finally Unearthed a National Treasure.” The New York Times (March 9, 2017).

Carter, Curtis L. "Ways of Worldmaking: J. R. R. Tolkien." In The Invented Worlds of J. R. R. Tolkien: Drawings and Original Manuscripts, from the Marquette. University Collection, October 21, 2004 - January 2005.

Carpenter, Humphrey. (editor with the assistance of Christopher Tolkien). The Letters of J. R. R. Tolkien. Boston: Houghton Mifflin, 1981.

Conrad-O'Brian, Helen and Gerard Hynes (editors). Tolkien: The Forest and the City. Four Court Press, 2013.

Cooper, Michael. “Can the Shed Redeem Hudson Yards?.” The New York Times (March 31, 2019).

Fimi, Dimitri and Thomas Honegger (editors). Sub-creating Arda: World-Building in J. R. R. Tolkien's Works, its Precursors, and Legacies. Walking Trees Publishers: Zurich and Berne, Switzerland, 2019.

Flierger, Verlyn. Splintered Light: Logos and Language in Tolkien's World. Kent and London: Kent State University Press, 2002.

Glaeser, Edward. Triumph of the City. New York: Penguin Press, 2011.

Glaeser, Edward. Triumph of the City. New York: The Penguin Group, 2011.

Goodman, Nelson. Ways of Worldmaking. Indianapolis: Hackett Publishing Company, 1978.

Goldberg, Barbara. "Hudson Yards Redraws New York Skyline.” Reuters (March 15, 2019).

Grant, Peter. "Hudson Yards Design is Like a Fortress.” The Wallstreet Journal (March 13, 2019).

Hughes, C. J. "Giants Within A City of Giants.” The New York Times (April 7, 2-19): 10.

Jacobs, Jane. The Death and Life of Great American Cities. New York: Random House, 1961.

J. R. R. Tolkien: The Hobbit: Drawings, Watercolors, and Manuscripts, Exhibition Catalogue. Milwaukee: Marquette University, June 11-September 30.

Kimmelman, Michael. "Hudson Yards is Manhattan's Biggest, Newest, Slickest Gated Community." The New York Times (March 14, 2019).

Lynch, Kevin. Image of the City. Cambridge, Massachusetts, 1960.

Mafi, Nick. "The Shed Finally Opens in New York City's Hudson Yards.” The New York Times (April 5, 2019).

Mumford, Lewis. The City in History: Its Origins, its Transformations and its Prospects. USA: Harcourt, Brace and World, 1961.

Plato, Republic, translated by G. M. A. Grube. Indianapolis, Hackett Publishing Co., 1992.

Schindler, Richard. The Expectant Landscape: J. R. R. Tolkien's Illustrations for the Hobbit.

Russeth, Andrew. "Stairway to Nowhere: on the Pleasure of Hating Thomas Heatherwisc's vessel in Hudson Yards." Art News (March 3, 2019). 


\section{GRADOVI KAO NAČINI STVARANJA SVETA}

\section{Curtis L. Carter}

Rad razmatra Tema "Načini stvaranja sveta" se pojavljuje u radovima filozofa poput Ernsta Kasirera (Ernst Cassirer) i Nelsona Gudmana (Nelson Goodman) (1906-1998.). Kasirer se ovom temom bavi u svom radu Jezik i mit (prevela Suzan Langer (Harper, 1946.)), a Gudman obrađuje "Načine stvaranja sveta" u svojoj istoimenoj knjizi (Hackett, 1978, 1981.). Oba filozofa navode umetnost kao ključan način za stvaranje sveta u svojoj funkciji različitih vrsta simbola. Prateći uvide Kasirera i Gudmana, "Načini stvaranja sveta" se ovde prvo razmatraju u odnosu na zamišljeni svet koji stvara uloge umetničkih dela koje se odnose na gradove. Primeri koji uključuju književna dela J. R. R. Tolkina, operu Kurta Veila i Bertolda Brehta, film kineskog umetnika Ksu Binga, njujorški Hadson Jards, najveći razvoj privatnih nekretnina u istoriji SAD-a do danas, se koriste kao primeri stvaranja sveta u umetnosti i razvoju gradova.

KLJUČNE REČI: STVARANJA SVETA, GRAD, TOLKIN, KURT VEIL / BERTOLD BREHT, KSU BING, HADSON JARDS, GUDMAN, KASIRER

\section{ZGRADE NAM GOVORE}

\section{Jale N. Erzen}

Polazeći od kritičkog pogleda na opšte arhitektonske i urbanističke strukture današnjice, ovaj rad će predstaviti zgrade koje se mogu porediti sa telom, tako što će njihov izraz i značenja koja imaju biti predstavljeni kao jezik forme koji utiče na ponašanje i psihologiju stanovnika u urbanim sredinama. Pozivajući se na arhitektonsku kritiku Žorža Bataja (George Bataille), tvrdi se da su fizički aspekti građevina značajni u onoj meri u kojoj prevazilaze materijalnost i vode ka simbolima i duhovnosti. Zgrade se posmatraju kao različite karakteristike i stavovi u zavisnosti od oblika. Arhitektura se takođe posmatra kao produkt rada i samim tim javna tvorevina koja svoje korene vuče iz korena ljudske kulture. Sve različite institucije su se istorijski razvijale iz različitih čula, postajući kulturna artikulacija i rezultirajući arhitekturama koja povezuje ljude u uživanju u zajedničkim interesovanjima. Dalje se tvrdi da urbani i prostorni oblici koji su zbunjujući u pogledu svojih granica i namena mogu izazvati konfuziju i negativne reakcije. Stoga je važno da jezik urbanih oblika bude pozitivan i jasan.

KLJUČNE REČI: ARHITEKTURA, TELO, JEZIK, FORMA, KULTURA

\section{ŠTA SE DOGODILO SA ESTETIKOM I UMETNOŠCU U PRETHODNIH 100 GODINA? PROTIVREČNOSTI I ANTAGONIZMI - RATOVI TEORIJA! \\ Miško Šuvaković}

Predmet ovog rada su dinamični i transformacioni odnosi između estetike i umetnosti od 1919. do 2019. godine. Prvi problem koji će se raspravljati biće odnos između umetnosti i politike u Bauhausu i umetničkih instituta Sovjetske avangarde. Zatim ću ukazati na razlike u marksističkim konceptima socijalističkog realizma i kritičkoj teoriji o modernoj kulturi i umetnosti. Analiziraću odnos između koncepta autonomije umetnosti, posebno slikarstva i minimalne umetnosti. Poređenje će biti izvedeno između anti-umetnosti (Dada, Neo-Dada) i anti-filozofije (Fridrih Niče, Ludvig Vitgenštajn, Žak Lakan). Osvrnuću se na pristupe od analitičke metaestetike do interpretacije Dišanovih redimejda, izvešću na osnovu toga teoriju umetnosti u konceptualnoj umetnosti. Posebna pažnja će se posvetiti "teorijskim sukobima" između fenomenologije i strukturalizma, kao i poststrukturalizma. Završiću svoju diskusiju identifikujući "estetski uslov” u odnosu na "savremenu umetnost" (feministička, aktivistička, politička, ekološka, participativna i aproprijacijska umetnost). 